\title{
全口蓋床を基準とした床設計への 適応性に関する音響学的考察
}

\author{
小塩 博司 \\ An Acoustico-Phonetic Observation Concerning An Adaptability \\ to the Plate Designing Based on Full Palatal Plates
}

Hiroshi Koshio

緒言

歯科補緅臨床上，各種補経装置が患者の発声標本に与 える種々の影響について多数 ${ }^{1 \sim 8)}$ 報告されてきたが, そ の影響は，しばしば患者個体の内的条件によって声道断 面積の面積関数に変動を与える要因 ${ }^{9 \sim 11)}$ となっている.

この内的条件は音声現象の物理的記述段階として, 波 形, 周波数スペクトル, 調音の 3 段階で論じられる が, 歯科学的領域としては患者個人の口蓋形態 ${ }^{1722)}$, 調

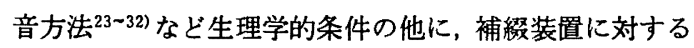
順応の程度という心理学的条件 ${ }^{33,34)}$ が混在し, 音声現象 に有意味な変化を表している.

また, 最近の話者認識システムの飛躍的な 発達によ り, 近い将来, 補緅装置による音声の変化を定常化する 方向人の補緅学的難題に取り組まなければならないと思 われる。

今回, 著者は, 補緅装置による個人音声への影響を追 求するために， 2 種類の実験的補綴装置を用いて日本語 5 母音音素についてそれぞれの影響の度合から起こり得 る個人特性について検索し, 各個人内での音響学的基準 を設定し, 全口蓋床の適応性から考虑した床設計を可能 にすることを目的として本実験を行った.

岐阜歯科大学歯科補緅学第 2 講座 (主任 : 山田早苗教授) 指導 : 藤井輝久教授 (岐自歯科大学歯科補経学第 3 满座) The Second Department of Prosthetic Dentistry, Gifu College of Dentistry (Chief : Prof. Sanae Yamada) Director: Prof. Teruhisa Fujii (The Third Department of Prosthetic Dentistry, Gifu College of Dentistry) 昭和 59 年 12 月 14 日受付
実験方法およひ装置

\section{1. 被験者 (Table 1)}

被験者は年齢 20〜24 歳の本学男子学生 10 名で, 出身 地は主に関西方面であり，比較的方言の少ないことお よび発声器官, 聴覚器官に異常がないことを条件とし た. また， 口腔内の条件として，上下頻とも歯の欠損， 補緅物がなく個性正常咬合を有しているものとした. 以 下, これらの被験者を $\mathrm{A} \sim \mathrm{J}$ のアルファベット記号にて 略記する.

\section{2. 実験的補綴装置}

アルギン酸印象材を用いて各被験者の上額を印象採得 した石亮模型上で，臨床における一般的な床設計にもと つき,つぎの 2 種類の実験的補緅装置を作製した.

a. 実験的全口蓋床 (Fig. 1)

総義歯を想定した装置で, Bioster 社製 Universal

Table 1 Present history of subjects

\begin{tabular}{c|ccc}
\hline \hline Subjects & Age & Sex & Born \\
\hline A & 23 & Male & Hiroshima \\
B & 23 & Male & Kyoto \\
C & 20 & Male & Kobe \\
D & 23 & Male & Osaka \\
E & 22 & Male & Kyoto \\
F & 23 & Male & Gifu \\
G & 20 & Male & Kobe \\
H & 22 & Male & Kyoto \\
I & 23 & Male & Kobe \\
J & 24 & Male & Kyoto \\
\hline
\end{tabular}




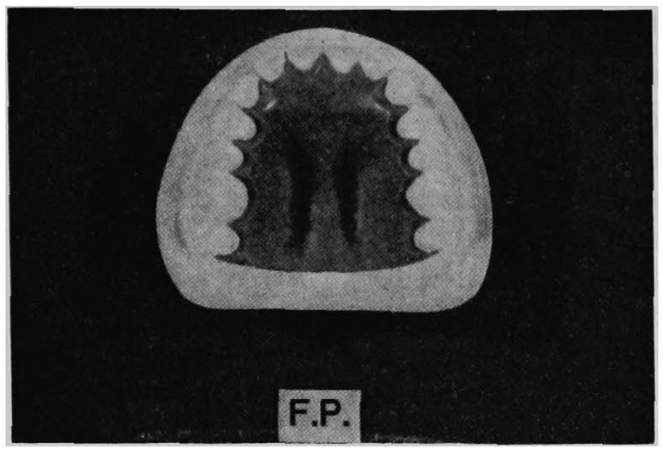

Fig. 1 Full palatal plate

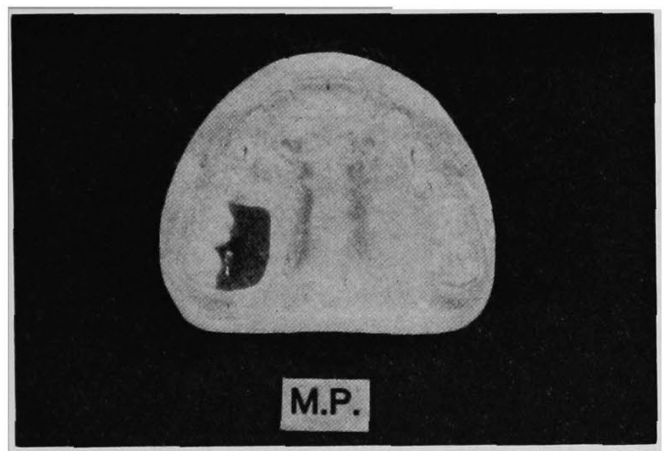

Fig. 2 Molar partial plate

Pressure Moulding Machine を使用して EIkodent 社 製 ELKOPLAST を軟化圧接し厚みは $1.5 \mathrm{~mm}$ とし，床 外形の後縁は $\underline{717}$ の遠心を結んだ線で自然移行させた. また，歯頸縁はすべての歯の舌側歯頸線に沿うようにト リミングし作製した. 以下，この装置を F.P. (Full palatal plate) と略記する.

b. 実験的局部床 (Fig. 2)

片側臼歯部遊離端義歯を想定した装置で，即時重合レ ジン (G-C 社製, Uni Fast) を使用して厚さ $1.5 \mathrm{~mm}$ と し， 床外形は 616 の近心面を結ぶ線から 717 の遠心面を 結ぶ線と, その右側 $1 / 4$ の点を結ぶ線の範囲とし床縁は 自然移行させた. 歯頸緣は76/の舌面に接触させた. ま た, 床の維持には瞬間接着剤 (Aron alpha) を用い歯面 に接着させた. 以下，この装置を M.P. (Molar partial plate) と略記する.

\section{3. 検査語表および検査語音}

日本語の標準母音 ( $V$ 型) 5 語と標準子音 (C.V. 型) 62 語を対象とし, それらをアトランダムに配列した単音 マトリックスを数種類使用し検查語表とした. また, 検 查語音は, これらのうち出力の安定した母音 5 語と子音
Table 2 Speech materials

\begin{tabular}{ccccc}
\hline $\mathrm{a}$ & $\mathrm{i}$ & $\mathrm{u}$ & $\mathrm{e}$ & 0 \\
$\mathrm{~Pa}$ & $\mathrm{Pi}$ & $\mathrm{Pu}$ & $\mathrm{Pe}$ & $\mathrm{Po}_{0}$ \\
$\mathrm{Ba}$ & $\mathrm{Bi}$ & $\mathrm{Bu}$ & $\mathrm{Be}$ & $\mathrm{Bo}$ \\
$\mathrm{Ka}$ & $\mathrm{Ki}$ & $\mathrm{Ku}$ & $\mathrm{Ke}$ & $\mathrm{Ko}_{0}$ \\
$\mathrm{Ga}$ & $\mathrm{Gi}$ & $\mathrm{Gu}$ & $\mathrm{Ge}$ & $\mathrm{G}_{0}$ \\
$\mathrm{Ma}$ & $\mathrm{Mi}$ & $\mathrm{Mu}$ & $\mathrm{Me}$ & $\mathrm{Mo}$ \\
$\mathrm{Na}$ & $\mathrm{Ni}$ & $\mathrm{Nu}$ & $\mathrm{Ne}$ & $\mathrm{No}_{0}$ \\
$\mathrm{Sa}$ & & $\mathrm{Su}$ & $\mathrm{Se}$ & $\mathrm{So}_{0}$ \\
$\mathrm{Za}$ & & $\mathrm{Zu}$ & $\mathrm{Ze}$ & $\mathrm{Z}_{0}$ \\
$\mathrm{Ta}$ & & & $\mathrm{Te}$ & $\mathrm{T}_{0}$ \\
$\mathrm{Da}$ & & & $\mathrm{De}$ & $\mathrm{Do}_{0}$ \\
\hline
\end{tabular}

44 語からセグメント化した母音の計 49 語（Table 2) を対象とした.

\section{4. 録音装置および方法}

a. 録音装置

・マイクロフォン: SONY 社製バック・エレクトレ ット・コンデンサーマイクロフォン ECM-56 A

・テープレコーダー：SONY 社製 TC-K8B

・テープ : SONY 社製, $\mathrm{Fe}-\mathrm{Cr}$ デュアード・カセット テープ

以上の装置を使用した.

b. 録音方法

防音室内にて被験者を口唇とマイクロフォンが $30 \mathrm{~cm}$ になるようにリラックスな状態で椅子に座らせ, 検查語 表を 1 音節ずつ約 2 秒の間隔で発声させテープレコーダ 一の V · U メーターの指針が $0 \mathrm{~dB}$ を越えないように一 定レベルのもとにカセットテープに入力し, 録音した.

\section{5. 音声分析装置および方法}

$\mathrm{KAY}$ 社製サウンドスペクトログラフ・6061 B 型を使 用し, テープレコーダーからの音声波出力を録音レベル が $0 \mathrm{~dB}$ を越えないように入力した. 分析には再生レべ ルが $-3 \mathrm{~dB}$ となるように調整し, $80 \sim 8,000 \mathrm{~Hz}$ 帯域の Line Scale で, Aught Gain Control 0.5, Mark Level を 2 として, 帯域幅 $300 \mathrm{~Hz}$ の広帯域フィルターを通し てサウンドスペクトログラムを得た. また, 同時に最大 振幅が $40 \mathrm{~dB}$ を越えないように Cross Section を描記し た.

採得したサウンドスペクトログラムから，第 1 ，第 2 , 第 3 フォルマントの中心周波数を計測し音声標本と した. 
Table 3 Sample means of formant frequencies

\begin{tabular}{|c|c|c|c|c|c|c|c|c|c|c|c|}
\hline \multicolumn{2}{|c|}{$/ \mathrm{a} /$} & A & B & C & D & $E$ & $\mathrm{~F}$ & $G$ & $\mathrm{H}$ & I & $\mathrm{J}$ \\
\hline \multirow{3}{*}{ OFF } & $\mathrm{F} 1$ & 659 & 704 & 698 & 684 & 694 & 701 & 703 & 620 & 779 & 755 \\
\hline & $\mathrm{F} 2$ & 1,265 & 1,243 & 1,328 & 1,274 & 1,300 & 1,281 & 1,267 & 1,199 & 1,244 & 1,310 \\
\hline & F3 & 2,405 & 2,310 & 2,483 & 2,466 & 2,460 & 2,516 & 2,522 & 2,266 & 2,353 & 2,566 \\
\hline \multirow{3}{*}{ F.P. } & F1 & 769 & 700 & 747 & 688 & 765 & 720 & 732 & 688 & 765 & 728 \\
\hline & $\mathrm{F} 2$ & 1,393 & 1,211 & 1,327 & 1,309 & 1,322 & 1,281 & 1,218 & 1,271 & 1,277 & 1,349 \\
\hline & F3 & 2,493 & 2,267 & 2,483 & 2,553 & 2.534 & 2,595 & 2,397 & 2.272 & 2,414 & 2,282 \\
\hline \multirow{3}{*}{ M.P. } & $\mathrm{F} 1$ & 681 & 705 & 740 & 780 & 784 & 707 & 700 & 669 & 743 & 755 \\
\hline & $\mathrm{F} 2$ & 1,307 & 1,235 & 1,366 & 1,391 & 1,374 & 1,271 & 1,262 & 1,212 & 1,330 & 1,359 \\
\hline & F3 & 2,332 & 2,236 & 2,489 & 2,510 & 2,503 & 2,594 & 2,591 & 2,263 & 2,397 & 2.402 \\
\hline
\end{tabular}

Table 4 Sample means of formant frequencies

\begin{tabular}{|c|c|c|c|c|c|c|c|c|c|c|c|}
\hline \multicolumn{2}{|c|}{$/ \mathrm{i} /$} & A & B & $\mathrm{C}$ & $\mathrm{D}$ & $\mathrm{E}$ & $F$ & G & $\mathrm{H}$ & I & $J$ \\
\hline \multirow{3}{*}{ OFF } & $F_{1}$ & 358 & 372 & 389 & 298 & 311 & 333 & 346 & 344 & 349 & 377 \\
\hline & $\mathrm{F} 2$ & 1,969 & 2,140 & 2,239 & 2,311 & 2,285 & 2,167 & 2,115 & 2,137 & 2,262 & 2,298 \\
\hline & $1 \% 3$ & 3,184 & 2,869 & $\cdot 3,051$ & 3,067 & 3,061 & 2,775 & 2,822 & 2,848 & 3,080 & 3,080 \\
\hline \multirow{3}{*}{ F.P. } & $\mathrm{F} 1$ & 393 & 295 & 369 & 292 & 373 & 337 & 391 & 360 & 377 & 384 \\
\hline & $\mathrm{F} 2$ & 2,169 & 1,650 & 1,640 & 1,603 & 1,692 & 2,071 & 2,008 & 1,978 & 1,959 & 1.717 \\
\hline & $\mathrm{F} 3$ & 2,914 & 2,468 & 2.547 & 2,306 & 2,588 & 2,686 & 2,574 & 2,699 & 2,821 & 2,407 \\
\hline \multirow{3}{*}{ M.P. } & $\mathrm{F} 1$ & 368 & 329 & 371 & 354 & 374 & 349 & 427 & 373 & 384 & 406 \\
\hline & $\mathrm{F} 2$ & 2,082 & 2,149 & 2,208 & 2,079 & 2,033 & 2,216 & 2,287 & 1,933 & 2,161 & 2,292 \\
\hline & $\mathrm{F} 3$ & 3,074 & 2,717 & 3,077 & 2,656 & 2,775 & 2,779 & 3,019 & 2,826 & 3,013 & 3,120 \\
\hline
\end{tabular}

$(\mathrm{Hz})$

Table 5 Sample means of formant frequencies

\begin{tabular}{|c|c|c|c|c|c|c|c|c|c|c|c|}
\hline \multicolumn{2}{|c|}{$|u|$} & A & B & $\mathrm{C}$ & $\mathrm{D}$ & $\mathrm{E}$ & $\mathrm{F}$ & G & $\mathrm{H}$ & I & $\mathrm{J}$ \\
\hline \multirow{3}{*}{ OFF } & $\mathrm{F} 1$ & 367 & 427 & 412 & 390 & 404 & 438 & 373 & 296 & 377 & 369 \\
\hline & $\mathrm{F} 2$ & 1,081 & 1,136 & 1,225 & 1,288 & 1,175 & 1,289 & 1,036 & 1,093 & 1,259 & 1,207 \\
\hline & F3 & 2,168 & 2,233 & 2,451 & 2,378 & 2,517 & 2,259 & 2,071 & 1,824 & 2,081 & 2,073 \\
\hline \multirow{3}{*}{ F.P. } & $\mathrm{F} 1$ & 395 & 359 & 428 & 362 & 430 & 411 & 358 & 333 & 400 & 364 \\
\hline & $\mathrm{F} 2$ & 1,153 & 1,103 & 1,230 & 1,283 & 1,137 & 1,271 & 957 & 1,032 & 1,094 & 1,033 \\
\hline & F3 & 2,279 & 2,213 & 2,361 & 2,341 & 2,398 & 2,361 & 2,116 & 1,829 & 2,158 & 1,756 \\
\hline \multirow{3}{*}{ M.P. } & F1 & 318 & 343 & 447 & 382 & 470 & 459 & 416 & 335 & 417 & 408 \\
\hline & $\mathrm{F} 2$ & 1.052 & 1,154 & 1,277 & 1,272 & 1,184 & 1,260 & 1,179 & 1,056 & 1,204 & 1,149 \\
\hline & $\mathrm{F} 3$ & 2,198 & 2,208 & 2,509 & 2,438 & 2,456 & 2,329 & 2,270 & 2,021 & 2,190 & 2,240 \\
\hline
\end{tabular}

\section{実験成精}

\section{1. 各装置装着時のフォルマント周波数の変動につい} $\tau$

Table 3〜7 は, 各被験者における検查語音の 5 母音お よび子音を語頭にもつ後続母音の未装着時（以下，これ を OFF と略記する) と, F.P., M.P. 装着時での第 1 , 第 2 , 第 3 フォルマント平均周波数（以下，これを $\mathrm{F}_{1}$,
$\mathrm{F}_{2}, \mathrm{~F}_{3}$ と略記する) を示した.

F.P., M.P. 装着時の各フォルマント周波数判定の基 準として, OFF のフォルマント周波数の標 準偏 差 (以 下，これを S.D. と略記する) から OFF とF.P., およ び M.P. 装着時の変動値 (Table 3 7) を求め, その変 化の有無，大きさおよび特徽について各装置別に観察 した. 
Table 6 Sample means of formant frequencies

\begin{tabular}{r|c|r|r|r|r|r|r|r|r|r|r}
\hline \multicolumn{2}{c|}{ / e } & \multicolumn{1}{c|}{ A } & \multicolumn{1}{c|}{ B } & \multicolumn{1}{c|}{ C } & \multicolumn{1}{c|}{ D } & \multicolumn{1}{c|}{ E } & \multicolumn{1}{c|}{ F } & G & H & I & \multicolumn{1}{c}{ J } \\
\hline \multirow{4}{*}{ OFF } & F1 & 449 & 556 & 487 & 490 & 517 & 556 & 466 & 405 & 476 & 580 \\
& F2 & 1,874 & 1,815 & 1,944 & 1,889 & 1,947 & 1,837 & 1,857 & 1,815 & 1,925 & 1,858 \\
& F3 & 2,505 & 2,452 & 2,581 & 2,638 & 2,644 & 2,506 & 2,602 & 2,512 & 2,591 & 2,649 \\
\hline \multirow{4}{*}{ F.P. } & F1 & 556 & 519 & 541 & 625 & 483 & 585 & 503 & 443 & 507 & 580 \\
& F2 & 1,908 & 1,776 & 1,970 & 2,114 & 1,890 & 1,845 & 1,714 & 1,760 & 2,012 & 1,600 \\
& F3 & 2,550 & 2,408 & 2,617 & 2,750 & 2,650 & 2,546 & 2,537 & 2,514 & 2,707 & 2,399 \\
\hline \multirow{4}{*}{ M.P. } & F1 & 442 & 557 & 546 & 631 & 564 & 602 & 491 & 419 & 515 & 583 \\
& F2 & 1,806 & 1,777 & 1,990 & 2,012 & 1,984 & 1,878 & 1,874 & 1,796 & 1,970 & 1,879 \\
& F3 & 2,528 & 2,400 & 2,630 & 2,672 & 2,698 & 2,551 & 2,686 & 2,506 & 2,657 & 2,686 \\
\hline
\end{tabular}

$(\mathrm{Hz})$

Table 7 Sample means of formant frequencies

\begin{tabular}{r|c|r|r|r|r|r|r|r|r|r|r|}
\hline \multicolumn{2}{c|}{ / o } & \multicolumn{1}{c|}{ A } & \multicolumn{1}{c|}{ B } & \multicolumn{1}{c|}{ C } & \multicolumn{1}{c|}{ D } & \multicolumn{1}{c|}{ E } & F & G & H & I & J \\
\hline \multirow{4}{*}{ OFF } & F1 & 476 & 522 & 502 & 499 & 533 & 609 & 444 & 465 & 485 & 519 \\
& F2 & 868 & 983 & 971 & 962 & 937 & 1,052 & 819 & 848 & 865 & 927 \\
& F3 & 2,426 & 2,357 & 2,565 & 2,550 & 2,508 & 2,505 & 2,122 & 1,827 & 2,218 & 2,263 \\
\hline \multirow{4}{*}{ F.P. } & F1 & 541 & 456 & 531 & 590 & 516 & 567 & 501 & 425 & 496 & 523 \\
& F2 & 983 & 998 & 1,032 & 1,049 & 956 & 1,021 & 870 & 857 & 940 & 991 \\
& F3 & 2,544 & 2,338 & 2,618 & 2,636 & 2,660 & 2,604 & 2,285 & 1,890 & 2,428 & 1,721 \\
\hline \multirow{4}{*}{ M.P. } & F1 & 482 & 485 & 541 & 601 & 559 & 597 & 468 & 434 & 537 & 500 \\
& F2 & 910 & 972 & 1,041 & 1,069 & 1,088 & 1,034 & 898 & 887 & 1,071 & 1,034 \\
& F3 & 2,275 & 2,302 & 2,578 & 2,579 & 2,522 & 2,631 & 2,045 & 2,041 & 2,318 & 2,125 \\
\hline
\end{tabular}

\section{a. F.P. 音響相の多元的観察}

i) $\mathrm{F}_{1}, \mathrm{~F}_{2}$ の様態

/a/ : F 1 で S.D. $43 \mathrm{~Hz}$ よりも大きな変動を示したもの は, 被験者Aの OFF 時 $651 \mathrm{~Hz}$ が F.P. 装着時 $769 \mathrm{~Hz}$ となり，その周波数差が $118 \mathrm{~Hz}$ であるのが最大で，つ いで被験者Eの OFF 時 $694 \sim 765 \mathrm{~Hz}$ でその差 $71 \mathrm{~Hz}$, 被験者 Hの OFF 時 $620 \sim 688 \mathrm{~Hz}$ でその差 $68 \mathrm{~Hz}$, 被験 者Cの 698〜 $747 \mathrm{~Hz}$ でその差 $49 \mathrm{~Hz}$ の順にフォルマン ト周波数に変動を示した. また, 被験者 B, D, F, G, I, J は OFF との間の周波数差は S.D. 以下の值を示し, 特 に被験者 Bの OFF 時 704 700 Hz, 被験者Dの OFF 時 $684 \sim 688 \mathrm{~Hz}$ の周波数変動で，その差は $4 \mathrm{~Hz}$ と最小值 を示した.

以後, OFF 時と F.P. 装着時の変動した周波数差だけ

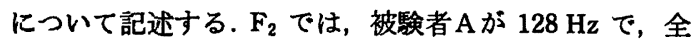
被験者中最も大きな数值を示し, ついで被験者 $\mathrm{H}$ の 72 $\mathrm{Hz}$, 被験者 $\mathrm{G} の ~ 49 \mathrm{~Hz}$, 被験者 $\mathrm{J} の 39 \mathrm{~Hz}$ の順となり, ともに $\mathrm{F}_{2}$ の S.D. $35 \mathrm{~Hz}$ よりも大きな周波数差を示し た.

/i/ : F 1 の S.D. は $27 \mathrm{~Hz}$ であり,これより 大きな周
波数差を示したものは, 被験者 $\mathrm{B} の ~ 77 \mathrm{~Hz}$ が最大で, ついで被験者 $\mathrm{E} の 62 \mathrm{~Hz}$, 被験者 $\mathrm{G} の 45 \mathrm{~Hz}$, 被験者 $\mathrm{A} の$ $35 \mathrm{~Hz}$, 被験者 I の $28 \mathrm{~Hz}$ の順であった.

$\mathrm{F}_{2}$ では, S.D. は $102 \mathrm{~Hz}$ であり, 被験者Dは $708 \mathrm{~Hz}$ の周波数差で最も大きな周波数変動を示した. また，他 の被験者にも大きな周波数差がみられ，被験者 C-E-J の順で，それぞれの周波数差は $599 \mathrm{~Hz}, 593 \mathrm{~Hz}, 581 \mathrm{~Hz}$ であった. また, 被験者 F は S.D. より小さい変動であ った.

/u/: $F_{1}$ の S.D. は $38 \mathrm{~Hz}$ であり, 被験者Bが $68 \mathrm{~Hz}$ の周波数差で，他の被験者は S.D. 以下の小さな值を示 した. $\mathrm{F}_{2}$ については, S.D. $85 \mathrm{~Hz}$ であり, 被験者 J と I がそれぞれ，周波数差 $174 \mathrm{~Hz}, 165 \mathrm{~Hz}$ と，他の被験者と 比へ特に大きな周波数変動を生じた.

le/ : F 1 の S.D. は $52 \mathrm{~Hz}$ であり, 被験者Dが $135 \mathrm{~Hz}$,

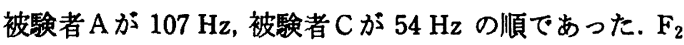
では，被験者 D, E, G, H, I, J が, S.D. $47 \mathrm{~Hz}$ よりも大 きな周波数変動を示し, その中でも特に, 被験者 $\mathrm{J}$ は周 波数差 $258 \mathrm{~Hz}$, 被験者 Dが $225 \mathrm{~Hz}$ と大きな周波数差を 示した。 
$38-564$

補緅誌

/o/: $F_{1}$ の S.D. は $43 \mathrm{~Hz}$ であり，被験者 D, B, A, G がそれぞれ $91 \mathrm{~Hz}, 66 \mathrm{~Hz}, 65 \mathrm{~Hz}, 57 \mathrm{~Hz}$ と S.D. の值を 越える周波数差であった. $\mathrm{F}_{2}$ については, 被験者 $\mathrm{A} の$ $115 \mathrm{~Hz}$ が最大で, ついで被験者Dの $87 \mathrm{~Hz}$, 被験者 I の $75 \mathrm{~Hz}$ に, S.D. $69 \mathrm{~Hz}$ 以上の周波数変動を示した.

ii） $\mathrm{F}_{3}$ の様態

/a/ : 被験者 Gと J の 2 名が S.D. $92 \mathrm{~Hz}$ よりも大きな 周波数変動を示したが, 他の 8 名の被験者には大きな周 波数変動を示すものはなかった.

/i/ : S.D. $133 \mathrm{~Hz}$ であり, 被験者Fのみ S.D. 以下の 周波数差で, 他の9名の被験者はすべて大きな周波数変 動を示した. 特に, 被験者Dの $761 \mathrm{~Hz}$, 被験者 J 673 $\mathrm{Hz}$, 被験者 Cの $504 \mathrm{~Hz}$ は，ともに S.D. よりも大きな周 波数差を示した.

/u/ : S.D. $197 \mathrm{~Hz}$ であり，被験者 J のみ $317 \mathrm{~Hz}$ と大 きく, 他の 9 名の被験者には S.D. 以上の周波数差を示 すものは 1 名もなかった.

/e/ : 被験者Dと I と Jが, それぞれ $112 \mathrm{~Hz}, 116 \mathrm{~Hz}$, $250 \mathrm{~Hz}$ と, S.D. $66 \mathrm{~Hz}$ 以上を示し, 特に, 被験者 Jの $250 \mathrm{~Hz}$ の周波数変動は顕著であった.

/o/ : 被験者 J を除く, 9 名の被験者が S.D. $221 \mathrm{~Hz}$ 以下の変動であったが, 被験者 Jについては $542 \mathrm{~Hz}$ と 大きく変動した.

b. M.P. 音響相の多元的観察

i) $\mathrm{F}_{1}, \mathrm{~F}_{2}$ の様態

/a/ : $F_{1}$ では, 被験者 D, E, H が, それぞれの周波数 差 $96,90,49 \mathrm{~Hz}$ と, S.D. 以上の周波数変動を示した. $F_{2}$ では, 被験者 A, C, D, E, I, J の6 名が S.D. 以上 の周波数変動を示し，その值の最大は被験 者 D 117 $\mathrm{Hz}$ で, 最小は被験者 $\mathrm{C}$ の $38 \mathrm{~Hz}$ であった.

/i/: $F_{1}$ では, 被験者 A, C, D を除く 7 名の被験者が S.D. 以上の周波数差を示し, 特に被験者 $\mathrm{G} の$ 周 波数差 $81 \mathrm{~Hz}$ が大きい変動であった. $\mathrm{F}_{2}$ では, 被験者 $\mathrm{A}, \mathrm{D}, \mathrm{E}$, G, H が S.D. 以上の周波数差を示し， $252 \mathrm{~Hz}$ を示した 被験者 Eが最大であった。

$/ \mathrm{u} /: \mathrm{F}_{1}$ では, 被験者 C, D, F を除く 7 名の被験者が S.D. 以上の値を示し，そのうち，被験者 Bの $84 \mathrm{~Hz}$ が 最大であった. $\mathrm{F}_{2}$ では, 被験者 $\mathrm{G}$ の $143 \mathrm{~Hz}$ と S.D. 以上の変動を示し，他の被験者はすべて S.D. 以下であ った.

le/ : $\mathrm{F}_{1}$ では，被験者 CおよびDの 2 名だけに S.D. 以上の周波数変動がみられた. $\mathrm{F}_{2}$ では, 被験者 $\mathrm{D}, \mathrm{A} の$ 2 名がそれぞれ $123,68 \mathrm{~Hz}$ と S.D. 以上の変動を示し た.
29 巻 3 号 (1985)

/o/: $\mathrm{F}_{1}$ では, 被験者Dが $102 \mathrm{~Hz}$ と特に大きな周波 数差を示し, 被験者 I が $52 \mathrm{~Hz}$ であった他は S.D. 以上 の周波数変動を示するのはなかった. $F_{2}$ では, 被験 者 C, D, E, G, I, J の 6 名の被験者が S.D. 以上の周波数差 を示し，そのうち被験者 I が $206 \mathrm{~Hz}$ と最大であった.

ii) $\mathrm{F}_{3}$ の様態

$\mid \mathrm{a} /$ : 被験者 $\mathrm{J}$ の周波数差 $164 \mathrm{~Hz}$ が S.D. 以上の周波 数差を示し，他は特に大きな変動を示したものはなかっ た.

/i/ : 被験者 B, D, E, G の 4 名が, S.D. 以上の周波数 差を示し，他の 4 母音と比ベて変動した被験者が多くみ られた. 特に, 被験者Dの $411 \mathrm{~Hz}$, 被験者 $\mathrm{E} の 286 \mathrm{~Hz}$ が大きな值であった.

/u/ : 被験者 G, H の 2 名がそれぞれ 199, $197 \mathrm{~Hz}$ と， 他の被験者に比ぺて大きな周波数変動を示した.

$|\mathrm{e}|$ : 被験者 Gと I の 2 名の他には, S.D. 以上の周 波 数差を示すものはなかった.

/o/ : 10 名の被験者すべてが S.D. 以下の值であった.

\section{2. 各被験者にみられる 5 母音の音響学的特徵} (Table 8, 9)

各被験者の $\mathrm{F}_{1}, \mathrm{~F}_{2}, \mathrm{~F}_{3}$ フォルマント周波数が, OFF 時 と比較して変動した母音のみ抽出して Table 8,9を作 成した。

Table 8 は OFF 時と F.P. 装着時を, Table 9 は OFF 時と M.P. 装着時を比較したもので, F.P. と M.P. を同 時に比較してその変化様式が共通する母音には*（アス タリスク)を付した.

a. フォルマントに変動を示す母音について

各被験者について $F_{1}, F_{2}, F_{3}$ における変化様式の特徴 を検討した。

・被験者 $\mathrm{A}: \mathrm{F}_{1}$ では，F.P. において変動したものは |a/, /i/, /e/, /o/ であったがこの 4 母音は M.P. では変動 を示さず，逆に F.P. で変動がなかった / / は M.P. で 変動した. $F_{2}$ においては, F.P., M.P. とも, /a/ と/i/ がともに共通して変動したが, /o/ は F.P.で/e/は M.P. でのみ変動を示した， $F_{3}$ においては，F.P.の/i/のみ変 動がみられた。

・被験者 $\mathrm{B}: \mathrm{F}_{1}$ では $/ \mathrm{i} /$ と $/ \mathrm{u} /$ が共通して変動し, $/ \mathrm{o} /$ は F.P.でのみ変動した. $F_{2}, F_{3}$ については, /i/ が F.P. で $\mathrm{F}_{2}, \mathrm{~F}_{3}$ の両者で変動したが, M.P. では $\mathrm{F}_{3}$ のみ共通 した変動を示した.

・被験者 C：F 1 においては, /e/ が両装固間で変動が 共通し, / / / は F.P.のみに変動を示した. $\mathrm{F}_{2}$ においては, 
Table 8 Acoustic features of the vowel formant deformation in the subjects (F.P.)

\begin{tabular}{|c|c|c|c|c|c|c|c|}
\hline & $\mathrm{F}_{1}$ & $\mathrm{~F}_{2}$ & $\mathrm{~F}_{3}$ & 0 & 1 & 2 & 3 \\
\hline A & a i eo & a ${ }^{*}$ i 0 & $\mathrm{i}$ & $\mathbf{u}$ & $\stackrel{*}{\mathrm{e}}$ & a o & j \\
\hline B & i üo & $\mathrm{i}$ & $\stackrel{*}{\mathrm{i}}$ & a e & üo & - & $\mathrm{i}$ \\
\hline $\mathrm{C}$ & $\mathrm{a} \mathrm{e}^{*}$ & $\mathrm{i}$ & $\mathrm{i}$ & u 0 & $\stackrel{* *}{\mathrm{a}} \mathrm{e}$ & $\mathrm{i}$ & - \\
\hline $\mathrm{D}$ & $\begin{array}{l}* * \\
\text { e o }\end{array}$ & a i e* o & i e & $\dot{u}$ & a & $\mathrm{i}{ }^{*}$ & e \\
\hline $\mathrm{E}$ & $\ddot{a}$ & $\stackrel{*}{\mathrm{i}} \mathrm{e}$ & i & uo & a e & - & i \\
\hline $\mathrm{F}$ & - & - & - & $\begin{array}{l}* * * * * * \\
\text { a i u e o }\end{array}$ & - & - & - \\
\hline G & io & $\mathrm{a} \dot{\mathrm{i}} \mathrm{e}$ & $a \stackrel{*}{i}$ & u & $\ddot{e}$ & $\mathbf{a}$ & $\stackrel{*}{\mathrm{i}}$ \\
\hline $\mathrm{H}$ & $\stackrel{*}{a}$ & $\mathrm{a}_{\mathrm{i}}^{*} \mathrm{e}$ & i & u & $e$ & $a \stackrel{*}{i}$ & - \\
\hline I & i & i ü o* o & $\mathrm{i}^{*}$ & $\mathbf{a}$ & ü & $\stackrel{*}{\mathrm{e}}$ & $\mathrm{i}$ \\
\hline$J$ & - & a i ue & a i ueo & - & $\stackrel{*}{0}$ & a i u e & - \\
\hline
\end{tabular}

Table 9 Acoustic features of the vowel formant deformation in the subjects (M.P.)

\begin{tabular}{|c|c|c|c|c|c|c|c|}
\hline & $F_{1}$ & $\mathrm{~F}_{2}$ & $\mathrm{~F}_{3}$ & 0 & 1 & 2 & 3 \\
\hline A & $\mathbf{u}$ & $\mathrm{a}$ i e & - & 0 & a i u & - & 一 \\
\hline B & $\stackrel{i}{*}^{*}$ & - & $\stackrel{*}{\mathrm{i}}$ & a * e o & u & $\mathrm{i}$ & - \\
\hline C & e & ao & - & $\mathrm{i} \dot{u}$ & a e o & - & - \\
\hline D & a i $e^{* *}$ & $\dot{*} \dot{i}^{* * *}{ }^{*}$ & i & $\dot{u}$ & - & a e $\stackrel{*}{o}$ & $\mathrm{i}$ \\
\hline $\mathrm{E}$ & $\ddot{a} \dot{i} u$ & a i o & $\dot{\mathrm{i}}$ & e & uo & a & i \\
\hline $\mathrm{F}$ & - & - & - & a ${ }^{*}$ i $^{*}$ u e ${ }^{*}$ o & - & - & - \\
\hline G & $\stackrel{*}{\mathrm{i} u}$ & ino & i u e & a & $\stackrel{* *}{\mathrm{e}} \mathrm{o}$ & - & iu \\
\hline H & a i u & $\mathrm{i}$ & $\mathrm{u}$ & e o & $\mathbf{a}$ & $\stackrel{*}{\mathrm{i} u}$ & - \\
\hline I & i uo & a u e* o & e & - & a i ${ }^{*}$ & èo & - \\
\hline $\mathbf{J}$ & i u & à 0 & a & e & i u ${ }^{*}$ & $\dot{a}$ & - \\
\hline
\end{tabular}

F.P. で/i/, M.P.で/a/, /o/が変動し，共通する母音はみ られなかった. $\mathrm{F}_{3}$ では, F.P.の/i/のみ変動がみられた.

・被験者 D : $\mathrm{F}_{1}$ の $/ \mathrm{e} /, \mathrm{l} /, \mathrm{F}_{2}$ の $/ \mathrm{a} /, \mathrm{i} /, / \mathrm{e} /, / \mathrm{o} /, \mathrm{F}_{3}$ の/i/ が両装置とも同じ変動を示し, F.P. では $F_{3}$ の/e/, M.P. では $\mathrm{F}_{1} の / \mathrm{a} /$ と/i/ が変動した.

・被験者 $\mathrm{E}: \mathrm{F}_{1}$ の / $\mathrm{a} /$ と $/ \mathrm{i} /, \mathrm{F}_{2}$ の /i $/, \mathrm{F}_{3}$ の/i/ が共 通した変動を示し， $F_{1}$ では M.P. の/u/, $F_{2}$ では F.P. の /e/, M.P.の/a/ と/o/ がそれぞれ単独に変動を示し た.

・被験者 $\mathrm{F}: \mathrm{F}_{1}, \mathrm{~F}_{2}, \mathrm{~F}_{3}$ とも変動を示す母音はみられ なかった.

•被験者 $\mathrm{G}: / \mathrm{i} /$ は F.P., M.P. とも $\mathrm{F}_{1}, \mathrm{~F}_{2}, \mathrm{~F}_{3}$ のすべ てが変動した他は $F_{1}$ では F.P.の/o/, M.P.の/u/, F では F.P.の/a/ と/e/, M.P.の/u/ と/o/, $\mathrm{F}_{3}$ では F.P.
の $\mid \mathrm{a} /$, M.P. の $\mid \mathrm{u} /$ と $\mid \mathrm{e} /$ がそれぞれ異なった変動様式 を示した.

・被験者 $\mathrm{H}: \mathrm{F}_{1}$ の $/ \mathrm{a} /, \mathrm{F}_{2}$ の/i/ が共通した变動を示 し, その他は $F_{1}$ の / i / と / $/$ / が M.P. のみ変動し, $F_{2}$ の/a/ と/e/はF.P.のみ変動した. F $F_{3}$ においては, F.P. の/i/ と M.P.の/u/がそれぞれ変動を示した.

・被験者 I : $\mathrm{F}_{1}$ の/i /, $\mathrm{F}_{2}$ の/u/, /e/, /o/, $\mathrm{F}_{3}$ の/e/ 加 共通した変動を示し， $F_{1}$ では M.P.の/u/ と/o/, $F_{2}$ では F.P.の/i/, M.P.の/a/, F それぞれ変動した。

・被験者 $\mathrm{J}$ : 共通して変動がみられるのは $\mathrm{F}_{2}$ と $\mathrm{F}_{3}$ の/a/のみであり, F.P. では $\mathrm{F}_{2}$ の/i/, / $/, / \mathrm{e} /, \mathrm{F}_{3}$ の/i/, $\mid \mathrm{u} /, / \mathrm{e} /, / \mathrm{o} /, \mathrm{M} . \mathrm{P}$. では $\mathrm{F}_{1}$ の $/ \mathrm{i} /$ と $/ \mathrm{u} /, \mathrm{F}_{2}$ の/o/ が個 有の変動を示した. 
Table 10 Pattern of formant deformation in the subjects

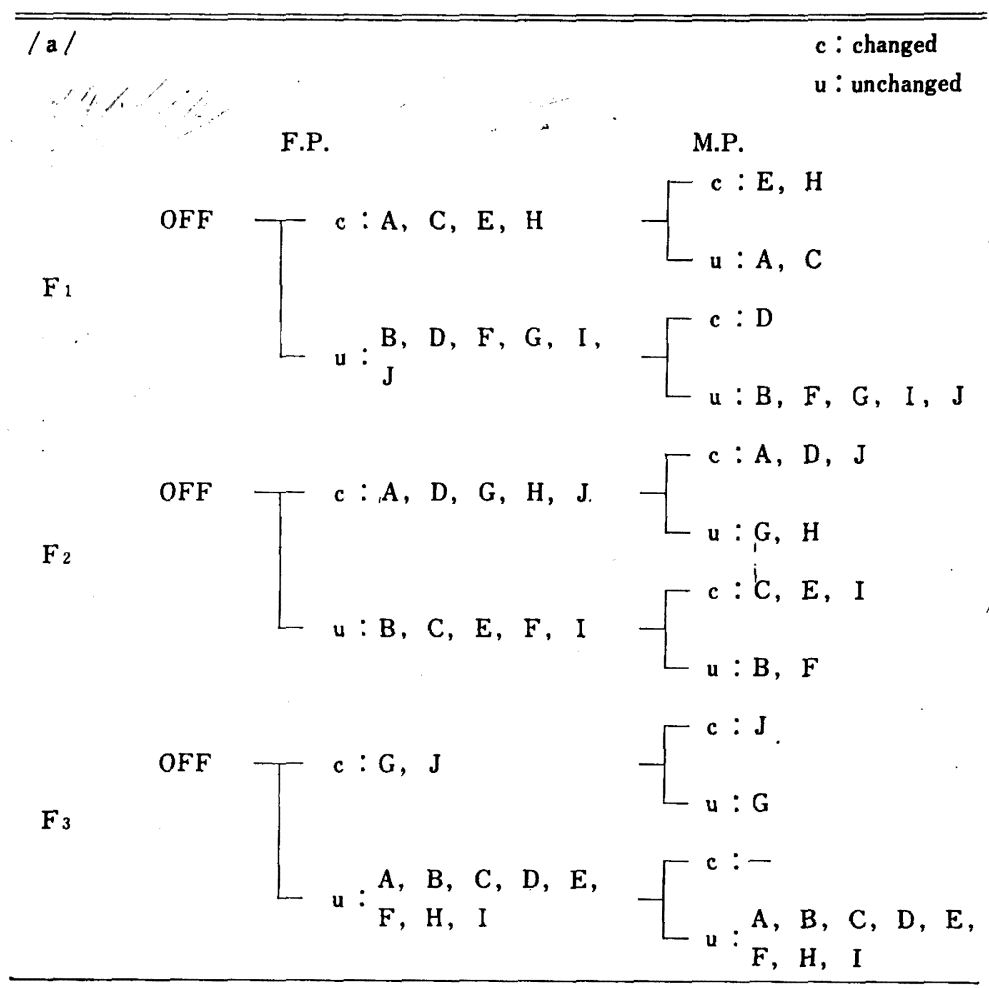

b. 変動を示すフォルマント個数について

Table 8, 9 の右に集計した母音のうち, F.P. と M.P. 間で共通してフォルマント周波数が変動した母音につい て検索した.

0 個，すなわち全くフォルマント周波数に変動がなか った母音は，被験者 $\mathrm{B} の / \mathrm{a} /$ と $/ \mathrm{e} /$, 被験者 $\mathrm{C} の / \mathrm{u} /$, 被 験者 $\mathrm{D} の / \mathrm{u} /$, 被験者 $\mathrm{H}$ の $/ 0 /$ で特に被験者 $\mathrm{F}$ は 5 母音す べてに両装置とも変動がなかった. 1 個変動したもの は, 被験者 $\mathrm{A} の / \mathrm{e} /$, 被験者 $\mathrm{B} の / \mathrm{u} /$, 被験者 $\mathrm{C} の / \mathrm{a} /$ と $\mathrm{le} /$, 被験者 $\mathrm{G}$ の $/ \mathrm{e} /$ と $/ \mathrm{o} /$, 被験者 $\mathrm{I} の / \mathrm{u} /$, 被験者 $\mathrm{J} の$ 10/, 2 個変動したものは, 被験者Dの $/ 0 /$, 被験者 $\mathrm{H} の / \mathrm{i} /$, 被験者 $\mathrm{I} の / \mathrm{e} /$, 被験者 $\mathrm{J}$ の/a/であり， 3 個変動したも のは, 被験者 $\mathrm{E}$ と被験者 $\mathrm{G} の / \mathrm{i} /$ であった.

以上記述したように, OFF と比較した F.P. と M.P. の 2 種類の装置の間に同じ変動をする母音と異なった変 動をする母音があり，また各被験者間においてもその変 化様式は多様性をきわめていた.

3. 両装置間での变化様式 (Table 10 14) 各被験者の両装置装着による 5 母音音素のフォルマン
卜周波数変動に対してそれらを総括的にみた類似点を求 め, それぞれの特徴を可及的に把握したグループに分類 することが可能かどうかを検討した 結果が Table 10〜 14 である.

表に示す $F_{1} F_{2}, F_{3}$ は各フォルマントを意味し，OFF 時と比較して，まず F.P. 装着時での各フォルマント周 波数の変化の有無を, 変化あり (changed), 変化なし (unchanged)の categorie に区分し，さらに，そのおの おのについて M.P. 装着時での変化の有無により10名 の被験者を item に細分した. この類別基準は，各被験 者の F.P., M.P. 装着時に 5 母音の $F_{1}, F_{2}, F_{3}$ フォルマ ント周波数上での変化に対して，各装圆間住け等関係 を対応うけ，また，変化の形式を類別する基準として 林 ${ }^{35,36)}$, 飽戸 ${ }^{37)}$ などの数量化理論に基ついた.

この類別基準によれば, 各被験者は各母音の各フォル マント周波数において，つぎの 4 つのクラスに分類する ことができる.

(1)：F.P. で変化があり，M.P. でも変化をするもの

(2) :F.P. で変化があり，M.P. では変化のないもの

(3) :F.P. で変化がなく,M.P. では変化をするもの 
Table 11 Pattern of formant deformation in the subjects

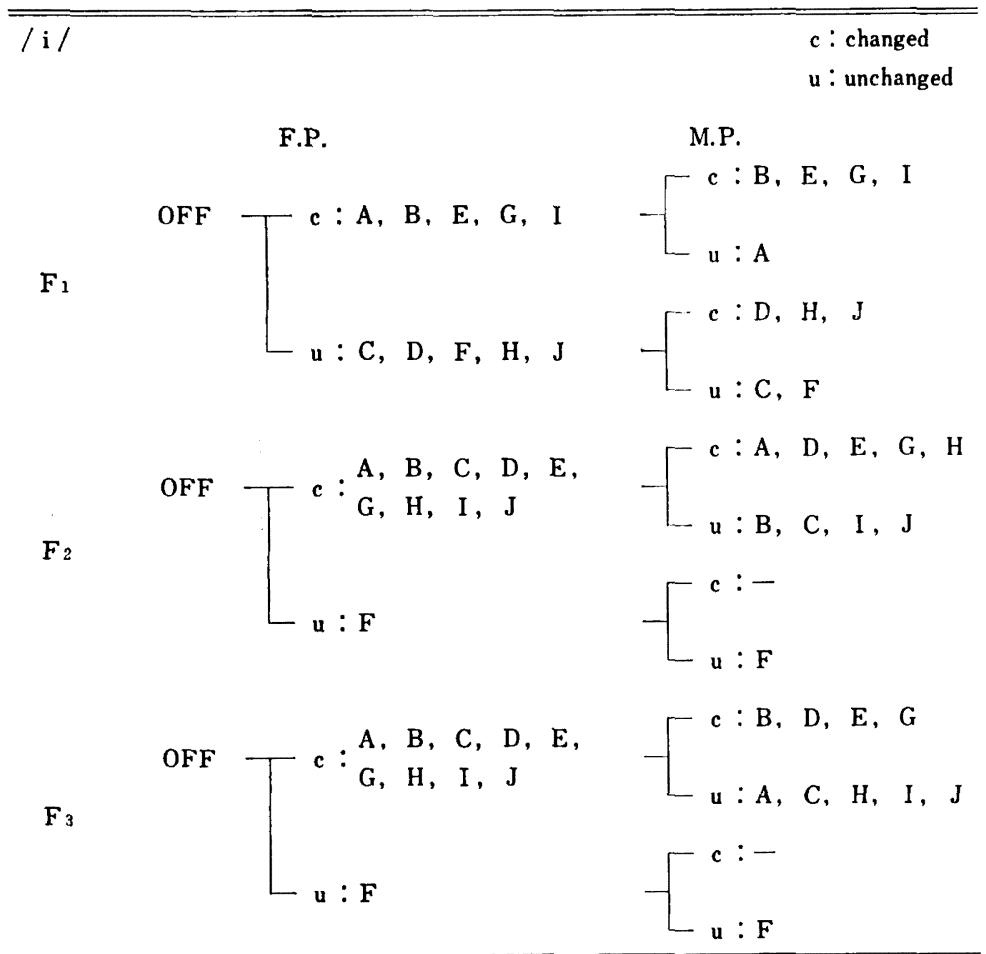

(4) : F.P. で変化がなく, M.P. でも変化のないもの Table 10 の /a/ の $F_{1}$ の右端の M.P. の下に列挙され た上から changed の被験者 $\mathrm{E}$ と $\mathrm{H}$ は(1)のクス, unchanged の被験者 A と C は(2)のクラス, changed の被験 者Dは(3のクラス, unchanged の被験者 B, F, G, I, J は(4)のクラスにそれぞれ分類されたことを表している.

ここで,さらに, これらの要因を含んだ各クラスを臨 床における発音を考虑した難易性から検討して, 柳井 ら ${ }^{38)}$ による順位尺度の得点付けを行った. その内容は Table 15 に示す通りである.

4. 変化㥞式の特徵よ Flexibility Scoreによる分類 Table 15 に示した得点付けから，10名の被験者の得 た各母音での各フォルマントの点数を示したものが Table 16 である.

合計数が最高の值を示したものは, 被験者 J で 47 点, 以下, 45 点の被験者 $G, 41$ 点の被験者 $A$ の 3 名が 40 点 以上であり，つぎに被験者 I が 37 点, 被験者 $\mathrm{H}$ が 35 点, 被験者 C, D, E が 31 点と同点を示し, 被験者 Bは 24 点で, 最小点は被験者Fの 15 点であった.
さらに,この表をもとに, 最む難易性の高いと思われ る 4 点を示したもののみについて観察するために，各母 音のもつ 3 つのフォルマントの中で 4 点を示すものが 1 つもないものを難易度 $0 ， 1$ 個あるものを難易度 $1 ， 2$ 個のものを難易度 2,3 個のものを難易度 3 とし, 集計 したものが Table 17 である.

右隅の Flexibility Score は, 難易度 1 は 1 倍, 難易 度 2 は 2 倍, 難易度 3 は 3 倍して数量化したもので, そ の特性をより顕著に表すことによって難易性を比較する 目安とした.

最も高い数值を示したものは被験者 J で 10 点, つい

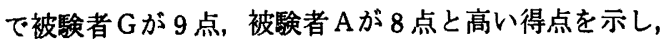
被験者 $\mathrm{H}$ と I が 6 点, 以下被験者 Cかi 5 点, 被験者 $\mathrm{E} か ゙$ 4 点, 被験者 $\mathrm{D} か ゙ 3$ 点, 被験者 $\mathrm{B} か ゙ 2$ 点となり，被験者 Fは得点 0 であった.

つぎに, Flexibility Score を得点別に 3 分割し，つぎ の 3 つのグループに大別した.

・第 1 グループ : 床設計が容易と思われるもの

・第 2 グループ : 床設計がやや困難と思われるもの

・第 3 グループ : 床設計が特に困難と思われるもの 
Table 12 Pattern of formant deformation in the subjects

\begin{tabular}{c}
\hline / u/ \\
F.P.
\end{tabular}

以上の 3 グループに被験者を該当させると，Table 18 に示すように, Flexibility Score 0〜4の比較的低い得 点を示した被験者 $\mathrm{B}, \mathrm{D}, \mathrm{E}, \mathrm{F}$ が第 1 グループに該当し， Flexibility Score 5〜7 の中間の得点を示した被験者 C, H, I が第 2 グループ, Flexibility Score 8〜10の高得点 を示した被験者 $\mathrm{A}, \mathrm{G}, \mathrm{J}$ が第 3 グループに該当した.

\section{考察}

\section{1. 音䅧学的基準設定}

a. 音声パターン（フォルマント周波数）変動の数量 化による類別

各被験者の OFF 時と， 2 種類の実験的補綴装置装着 時の 5 母音の音声標本の第 1 ，第 2 ，第 3 フォルマント 周波数の変化の関係を対応うけ，また，それらを類別す る基準としてつぎの 4 つのクラスに分類し，さらにそれ らのクラスに臨床における難易性を考慮して点数によ るランク付けを行った. i） F.P. で変化があり, M.P. でも変化をするもの ( 2 点)

一般的に，床の設計の基準の 1 つとして床面積が大き ければ，声道断面積の一部である口腔内容積の減少すな わち共鳴腔が縮小する，したがって，床面積を小さくす ることによって音響管の容積変化 $29,39,40)$ に影響を与えな いような考慮が必要であるとされているが, このクラス は，床面積の大小にかかわらず発音に変化を受けやす く，口蓋床の形態の変化がそのまま発音に対する影響度 として表れないものと考えられる.

ii） F.P. で変化があり，M.P. では変化のないもの ( 4 点)

このクラスは従来の調音音声学的観点から考えれば, 発音の変化に対する影響度はごく一般的29,40,41)である. 臨床において，床設計時に床面積の可及的な縮小が発音 への影響度を少なくできるクラスと考えられる.

iii） F.P. で変化がなく，M.P. では変化をするもの (4点)

このクラスは音声学上, 調音音声学で説明のつかない 
Table 13 Pattern of formant deformation in the subjects

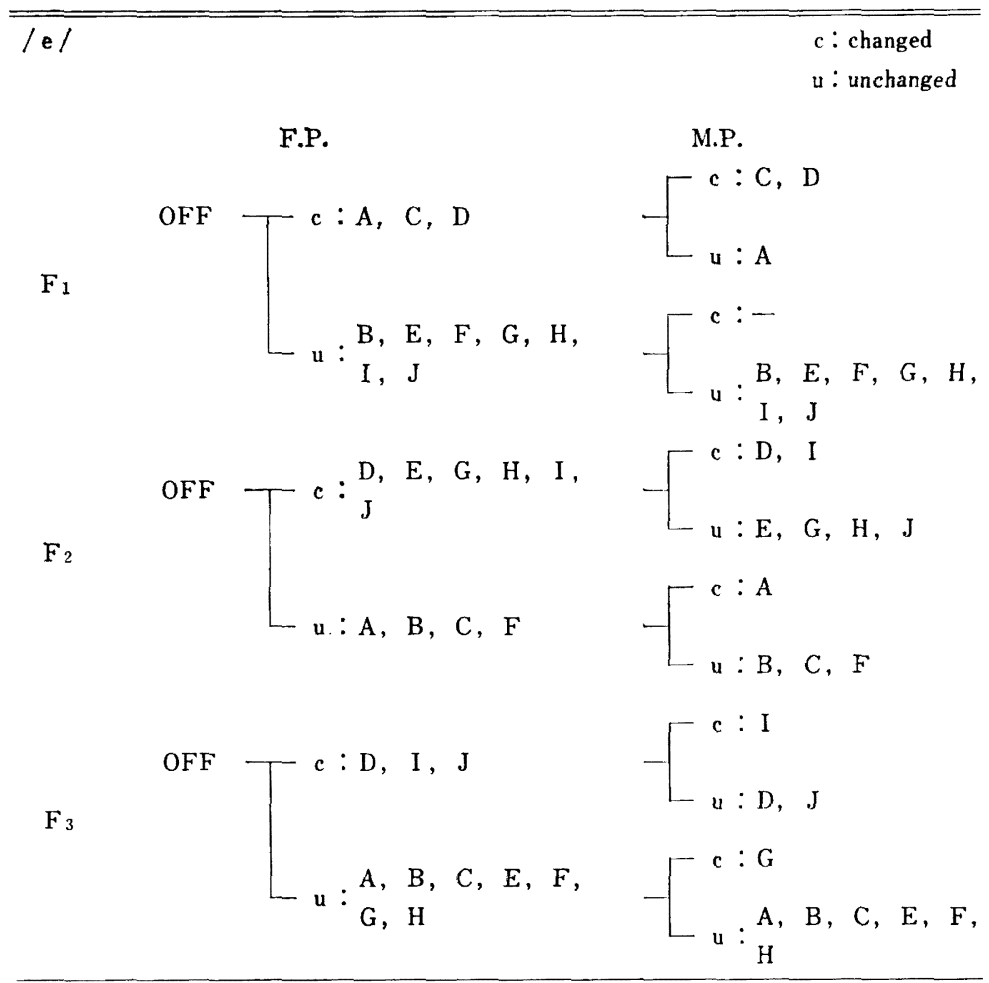

クラス ${ }^{20,40 \sim 44)}$ であり，床面積による口腔内容積の減 少 が, 大きいものよりも小さいものの方が発音の変化を受 けやすいという特異的な性質を表している.これは音声 学上，調音的にも，音響的にも予知できない要素 ${ }^{45)}$ が含 まれていると考えられるが，床設計時に片側性の欠損補 緅ではできるだけ口蓋全体を総体的に被覆するよう考慮 すれば影響を受けにくくなるのではなかろうかとも考え られる.これもまた, 床設計に際して細心の注意が必要 なクラスである.

iv） F.P. で変化がなく, M.P. でも変化のないもの (1 点)

このクラスは臨床上特に問題がなく, 床面積の影響を あまり考虑する必要がないと考えられる.

以上のように4つのクラスに分類し，また，それぞれ を点数にてランク付けを行った. その結果は実験成績の Table 16 に示した通りである.

b. Flexibility Scoreによる類別基準

a. の類別にもとついて, さらに臨床上難易性の高いと 思われる床面積の大小によって, それらのフォルマント
周波数に変動を受けやすいもの（4点を示すもの）につ いて論究する.

各母音の $\mathrm{F}_{1}, \mathrm{~F}_{2}, \mathrm{~F}_{3}$ の 3 つのフォルマントの中で 4 点 を示すものが，1個あるものを難易度 $1 ， 2$ 個あるもの を難易度 $2 ， 3$ 個あるものを難易度 3 とし, さらに難易 度の 2 乗として数量化したものの合計点数を難易得点 (Flexibility Score) として, その得点数により 3 つのグ ループに大別した.

・第 1 グループ :

（被験者）(Flexibility Score)

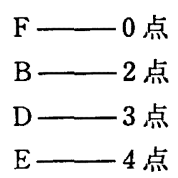

これらの被験者は Flexibility Score が低い点数を示 しており，臨床において床外形による発音への影響が少 ないものと考えられ，休設計が比較的容易と思われる.

・第 2 グループ:

(被験者) (Flexibility Score) 
Table 14 Pattern of formant deformation in the subjects

$\mathrm{c}:$ changed
$\mathrm{u}:$ unchanged

F.P.

M.P.

$$
F_{1}
$$$$
\text { OFF }
$$$$
\left[\begin{array}{l}
c: A, B, D, G \\
\text { u : } \begin{array}{l}
\mathrm{J} \\
\mathrm{J}, \mathrm{E}, \mathrm{F}, \mathrm{H}, \mathrm{I},
\end{array}
\end{array}\right.
$$

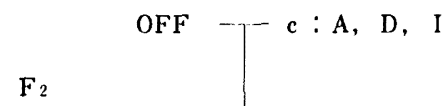

$B, C, E, F, G$, H, J

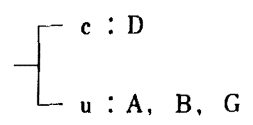

$$
\begin{aligned}
& \mathrm{C}-5 \text { 点 } \\
& \mathrm{H}-6 \text { 点 } \\
& \mathrm{I}-6 \text { 点 }
\end{aligned}
$$

これらの被験者は Flexibility Score が中間の点数を 示しており，臨床において床外形による発音への影響が やや多いと考えられ，床設計が比較的困難なものと推測 される.

・第 3 グループ :

(被験者) (Flexibility Score)

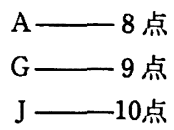

これらの被験者は Flexibility Score が高得点を示し ており，臨床において床外形による発音への影響度は特 に強いと考えられ，床設計が困難であると推測される.

\section{2. 各ケループについての特徴とクループ間での相遳 点および類別される要点基洀}

3 つのグループの分類を定義づけるために, 各グルー プ内での被験者の特徴と被験者間の類似点について,
Table 15 Formant deformation categories and scores

1）F.P.で変化があり，M.P.でも変化をするもの …2 点

2）F.P.で変化があり，M.P.では変化のないもの…...4 点

3）F.P.で変化がなく，M.P.では変化をするもの…..4 点

4) F.P.で変化がなく、M.P.でも変化のないもの…..1 点

OFF 時に対応する F.P., M.P. との間のフォルマント周 波数の変化椂式と, Flexibility Score の 2 つの観点から 考察した.

a. 5 母音音素の各フォルマントの変化様式からの類 別基準 (Table 19)

Table 19 は, 前述の Table 16 を変換したもので, $\triangle O @ \times$ あり，OFF 時と比較して， $\triangle$ は F.P. で変化があり M.P. でも変化をするもの，Oは F.P. で変化があり M.P. で は変化のないもの, @は F.P. で変化がなく M.P.では 変化をするもの， メは F.P. で変化がなく M.P. でも変 化のないものを示している． また，それぞれの記号を横 $\mathbf{\mathbf { \Sigma }}$ に $\mathrm{F}_{1}-\mathrm{F}_{2}-\mathrm{F}_{3}$ の順に並へた。. 
Table 16 Formant deformation scores of five vowels

\begin{tabular}{|c|c|c|c|c|c|c|c|c|c|c|c|c|c|c|c|c|}
\hline & $F_{1}$ & $\begin{array}{l}\mathrm{a} \\
\mathrm{F}_{2}\end{array}$ & $\mathrm{~F}_{3}$ & $F_{1}$ & $\begin{array}{l}\mathrm{i} \\
\mathrm{F}_{2}\end{array}$ & $F_{3}$ & $F_{1}$ & $\begin{array}{l}\mathrm{u} \\
\mathrm{F}_{2}\end{array}$ & $F_{3}$ & $F_{1}$ & $\begin{array}{l}\mathrm{e} \\
\mathrm{F}_{2}\end{array}$ & $\mathrm{~F}_{3}$ & $F_{1}$ & $\begin{array}{l}\mathrm{o} \\
\mathrm{F}_{2}\end{array}$ & $\mathrm{~F}_{3}$ & Total \\
\hline A & 4 & 2 & 1 & 4 & 2 & 4 & 4 & 1 & 1 & 4 & 4 & 1 & 4 & 4 & 1 & 41 \\
\hline B & 1 & 1 & 1 & 2 & 4 & 2 & 2 & 1 & 1 & 1 & 1 & 1 & 4 & 1 & 1 & 24 \\
\hline C & 4 & 4 & 1 & 1 & 4 & 4 & 1 & 1 & 1 & 2 & 1 & 1 & 1 & 4 & 1 & 31 \\
\hline D & 4 & 2 & 1 & 4 & 2 & 2 & 1 & 1 & 1 & 2 & 2 & 4 & 2 & 2 & 1 & 31 \\
\hline$E$ & 2 & 4 & 1 & 2 & 2 & 2 & 4 & 1 & 1 & 1 & 4 & 1 & 1 & 4 & 1 & 31 \\
\hline$F$ & 1 & 1 & 1 & 1 & 1 & 1 & 1 & 1 & 1 & 1 & 1 & 1 & 1 & 1 & 1 & 15 \\
\hline G & 1 & 4 & 4 & 2 & 2 & 2 & 4 & 4 & 4 & 1 & 4 & 4 & 4 & 4 & 1 & 45 \\
\hline $\mathrm{H}$ & 2 & 4 & 1 & 4 & 2 & 4 & 4 & 1 & 4 & 1 & 4 & 1 & 1 & 1 & 1 & 35 \\
\hline I & 1 & 4 & 1 & 2 & 4 & 4 & 4 & 4 & 1 & 1 & 2 & 2 & 4 & 2 & 1 & 37 \\
\hline $\mathbf{J}$ & 1 & 2 & 2 & 4 & 4 & 4 & 4 & 4 & 4 & 1 & 4 & 4 & 1 & 4 & 4 & 47 \\
\hline
\end{tabular}

Table 17 Acoustic flexibility

\begin{tabular}{c|cccc}
\hline & Flex.1 & Flex.2 & Flex.3 & Flex.Score \\
\hline A & 2 & 3 & - & 8 \\
B & 2 & - & - & 2 \\
C & 1 & 2 & - & 5 \\
D & 3 & - & - & 3 \\
E & 4 & - & - & 4 \\
F & - & - & - & 0 \\
G & - & 3 & 1 & 9 \\
H & 2 & 2 & - & 6 \\
I & 2 & 2 & - & 6 \\
J & - & 2 & 2 & 10 \\
\hline
\end{tabular}

Table 18 Acoustico-phonetic categories of the subjects to flexibility

\begin{tabular}{|c|}
\hline $\begin{array}{c}\text { 第1 グループ: 床設計が容易と思われるもの }(0-4) \\
\text { BDEF }\end{array}$ \\
\hline $\begin{array}{c}\text { 第 } 2 \text { グループ: 床設計がやや困難と思われるもの }(5 ７) \\
\text { CHI }\end{array}$ \\
\hline $\begin{array}{c}\text { 第3 グループ：床設計が特に困難と思われるもの（8～10) } \\
\text { AGJ }\end{array}$ \\
\hline
\end{tabular}

フォルマントの変化様式については $\mathrm{F}_{1}, \mathrm{~F}_{2}$ に関して 各グループの類別基準としての傾向は多少認められた が, 各被験者の個々の特異性が強く複雑さが含まれてい た.

しかし， $F_{3}$ についてはその変化様式が母音によって統 一的な結果が出ており，グループの類別基準の 1 つし て適用できるのではないかと思われる.すなわち, / i/ を 除いた母音では，大半が F.P., M.P. ともに変化がない という変化様式をとっているが，第 1 グループでは /a/ と $/ \mathrm{u} /$ と $/ 0 /$ はすべての被験者がその変化様式をとって おり，また，第 2 グループはこれから / / を除いた la/
と $/ 0 /$ が同様の変化様式を示していた，また, /i/ につい ては, 被験者 $\mathrm{F}$ を除くすへてての被験者に二様の変化様式 が示されており，第 1 グループは F.P., M.P. ともに変 化をする変化様式，第 2 グループ全員の被験者と被験者 G 除く第 3 グループが F.P. で変化があり, M.P. で変 化がないという変化様式をとっていることが特徴的であ る.

b. 難易度を示す母音からの類別基準 (Table 20)

Table 20 に各グループの被験者が有するそれぞれ 難 易度 1 ，難易度 2 ，難易度 3 を示した母音を表した.

i）第 1 グループの特徴

被験者 Bの /i/ と /o/, 被験者 Dの /a/ と / i / と /e/, 被 験者 $\mathrm{E} の / \mathrm{a} /$ と $/ \mathrm{u} /$ と $/ \mathrm{e} /$ と $/ \mathrm{o} /$ は難易度 1 を示し, 被 験者 Fは難易度を示す母音はなかった. このグループは 第 2 , 第 3 グループと比較して難易度 2,3 を示すもの がなく, Flexibility Score から臨床上床設計が容易なグ ループと思われる.

ii）第 2 グループの特徵

第 1 グループと比較して, このグループは難易度 2 を 示す母音がある. 被験者 Cが $/ \mathrm{a} /$ と / i /, 被験者 $\mathrm{H}$ が $/ \mathrm{i} /$ と $/ \mathrm{u} /$, 被験者 I が $/ \mathrm{i} /$ と $/ \mathrm{u} /$ で, それぞれ 2 母音ずつあ り, / i/ はすべてに共通する難易性を示しているのが特徴 的である. Flexibility Score から臨床上床設計がやや困 難なグループと思われる.

\section{iii）第 3 グループの特徽}

このグループは, 難易度 2 および難易度 3 を示す母音 が 3 個もしくは 4 個あり，その内容は被験者 Aが難易度 2 の母音 $\mid \mathrm{i} /$ と $/ \mathrm{e} /$ と $/ \mathrm{o} /$, 被験者 $\mathrm{G}$ が難易度 2 の母音 $\mid \mathrm{a} /$ と $/ \mathrm{e} /$ と $/ \mathrm{o} /$, 難易度 3 の母音 $/ \mathrm{u} /$, 被験者 $\mathrm{J}$ が難易度 2 の母音 $/ \mathrm{e} /$ と $/ 0 /$, 難易度 3 の母音 $/ \mathrm{i} /$ と $/ \mathrm{u} /$ をそれぞ れ有しており, 特に難易度 2 の母音では / / / と / / $/$ が共 
Table 19 Pattern formation to the vowels of the subjects

\begin{tabular}{|c|c|c|c|c|c|c|}
\hline & & $|\mathrm{a}|$ & $/ i /$ & $/ u /$ & $/ \mathrm{e} /$ & 101 \\
\hline & & $\mathrm{Fl}-\mathrm{F}_{2}-\mathrm{F}_{3}$ & $\mathrm{~F} 1-\mathrm{r} 2-\mathrm{F} 3$ & $\mathrm{~F} 1-\mathrm{F}_{2}-\mathrm{F}_{3}$ & $\mathrm{~F} 1-\mathrm{F} 2-\mathrm{F} 3$ & $\mathrm{~F} 1-\mathrm{F}_{2}-\mathrm{F}_{3}$ \\
\hline \multirow{4}{*}{ 1st group } & B & $x-x-x$ & $\Delta-O-\Delta$ & $\Delta-x-x$ & $x-x-x$ & $0-x-x$ \\
\hline & D & (O) $-\Delta-x$ & (a) $-\Delta-\Delta$ & $x-x-x$ & $\Delta-\Delta-O$ & $\Delta-\Delta-X$ \\
\hline & E & $\Delta-(-\times$ & $\Delta-\Delta-\Delta$ & (a) $-x-x$ & $x-0-x$ & $x-(0)-x$ \\
\hline & F & $x-x-x$ & $x-x-x$ & $x-x-x$ & $x-x-x$ & $x-x-x$ \\
\hline \multirow{3}{*}{2 nd group } & C & $0-(0-x$ & $x-0-0$ & $x-x-x$ & $\Delta-x-x$ & $x-(0-x$ \\
\hline & II & $\Delta-O-x$ & $0-\Delta-O$ & (0) $-x-(0)$ & $x-0-x$ & $x-x-x$ \\
\hline & I & $x-(0)-x$ & $\Delta-O-O$ & (0) $-0-x$ & $x-\Delta-\Delta$ & (D) $-\Delta-x$ \\
\hline \multirow{3}{*}{ 3rd group } & $A$ & $0-\Delta-x$ & $O-\Delta-O$ & (o) $-x-x$ & $0-@-x$ & $0-0-x$ \\
\hline & G & $x-0-0$ & $\Delta-\Delta-\Delta$ & ()-@-@ & $x-0-0$ & $0-0-x$ \\
\hline & $\mathrm{J}$ & $x-\Delta-\Delta$ & (a) $-0-0$ & (a) $-\mathrm{O}-\mathrm{O}$ & $x-0-0$ & $x-(0-0$ \\
\hline
\end{tabular}
$\triangle:$ P.P. $-\mathrm{C}$
(C) : F.P. $-\mathrm{U}$
O: F.P. $-\mathrm{C}$
$\times:$ F.P. $-U$
$\left(\begin{array}{l}C-\text { Clianged } \\ \text { U- Unchanged }\end{array}\right)$

Table 20 Vowel distribution on flexibility degree

\begin{tabular}{|c|c|c|c|c|}
\hline & & Flex. 1 & Flex. 2 & Flex. 3 \\
\hline $1 \mathrm{st}$ group & $\begin{array}{l}B \\
D \\
E \\
F\end{array}$ & $\begin{array}{lll}\mid \mathrm{i} / & / \mathrm{o} / \\
/ \mathrm{a} / \mathrm{i} / & / \mathrm{e} / & \\
/ \mathrm{a} / & / \mathrm{u} / \mathrm{e} / / \mathrm{o} /\end{array}$ & 一 & 一 \\
\hline 2nd group & $\begin{array}{l}\mathrm{C} \\
\mathrm{H} \\
\mathrm{I}\end{array}$ & $\begin{array}{lll} & 1 \mathrm{o} / \\
/ \mathrm{a} / & / \mathrm{e} / & \\
\mathrm{a} / & / \mathrm{o} /\end{array}$ & $\begin{aligned} / \mathrm{a} / \mathrm{i} / & \\
& / \mathrm{i} / \mathrm{u} / \\
& / \mathrm{i} / \mathrm{u} /\end{aligned}$ & - \\
\hline 3 rd group & $\begin{array}{l}\mathrm{A} \\
\mathrm{G} \\
\mathrm{J}\end{array}$ & $/ \mathrm{a} / \mathrm{u} /$ & $\mid \begin{array}{ll}\mid \mathrm{i} / & / \mathrm{e} / \\
/ \mathrm{a} / & / \mathrm{e} / \mathrm{o} / \\
& / \mathrm{e} / \mathrm{o} /\end{array}$ & $\begin{array}{r}/ \mathrm{u} / \\
/ \mathrm{i} / \mathrm{u} /\end{array}$ \\
\hline
\end{tabular}

通した難易性を示しているのが特徵的であった. Flexibility Score からこのグループは臨床上床設計が特に困 難なグループと推察される.

総 括

被験者 $\mathrm{A} \sim \mathrm{J}$ について, F.P., M.P. の 2 種類の装置を 用いて OFF 時と比較したフォルマント周波数の変化の
発現に対して変化様式を区別し検討を重ねた。

この変化様式から,さらに, 数量化された 難易 得点 (Flexibility Score)により，これを最終的類別基準とし てグループ分けを行った. この結果、臨床上床設計が容 易と思われるもの(第 1 グループ : 被験者 B, D, E , F)， やや困難と思われるもの（第 2 グループ : 被験者 C, H, I), 特に困難と思われるもの（第 3 グループ：被験者 $\mathrm{A}$, G, J) の 3 つのグループに大別された. 


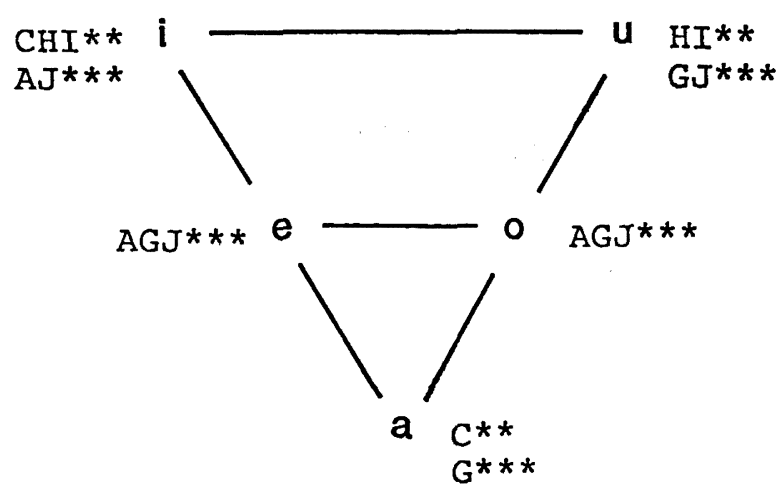

CHI : 2nd group**

AGJ : 3 rd group $* \star *$

Fig.3 Symmetrical arrangement of flexibility

第 1 グループは各母音とも強い難易性を示さなかっ た. ここで，第 2 ，第 3 グループについて，グループ内 での各被験者の有する高い難易性を示した母音を, Jones, 橋本など ${ }^{46 \sim 52)}$ の母音体系と関連させて，それらの 特徵を考察してみた（Fig. 3).

顎の開きの観点からでは, 第 2 グループは狭母音 /i/ と/u/の一方もしくは両方に高い難易性を示したが, 半 広母音 $\mid \mathrm{e} /$ と $10 /$ に畆高い難易性を示さなかった. 第 3 グループは狭母音 $/ \mathrm{i} /$ と / $\mathrm{u} /$ の一方もしくは両方に難易 性が高く，また，半広母音 / e/ と/0/の両方でも難易性 が高かった。 なお，広母音 / / / に高い難易性を示した被 験者は第 2 グループの被験者 C, 第 3 グループの被験者 $\mathrm{G}$ のみであった.

つぎに, 声道の狭めの位置から考察してみると, 前舌 母音 /i/ と/e/のうち, / i/ には第 2 グループ全員と第 3 グループの被験者 $\mathrm{A}$ と J, / / には第 2 グループにはなく 第 3 グループの被験者全員が高い難易性を示していた. また, 後舌母音 $10 /$ に難易性の高い被験者は第 3 グルー プの被験者全員であった.

今回の実験から，補緙装置による音響学的変化様式の 複雑さが関与する個人特性を, 全口蓋床 F.P.を基準と した音声標本から算出した床設計の基準設定により分類 した.この分類により臨床における発音での適応性とい う概念からこれにもとついた床設計の指標になるもの と思われる.

\section{結論}

1. 実験的全口蓋床 (F.P.) と局部床 (M.P.) は, 被 験者毎で異なった母音のフォルマントに影響を与えた。

2. 全口蓋床 (F.P.) による音響学的変化を 2 つに類 別すると,F.P. で影響を受けるもの受けないものは，さ らに下位分類されて，M.P. の影響を受けるもの受けな いものに細分された.

3. 音響学的類別基準として難易得点 (Flexibility Score）を設定すると，被験者は床設計が容易と思われる もの, やや困難と思われるもの, 特に困難と思われるも のの 3 つのグループに分かれた.

4. 予測が特に困難と考えられるグループに共通し て, 著しいフォルマント変化様式を示した母音は半広母 音/e/と/o/であった.

稿を終るにあたり，終始ご指導を賜り，また本論文のご校閱 在いただいた本学歯科補緅学第 3 講座，藤井輝久教授ならびに ご指導、ご鞭䔲を賜りました本講座, 倉知正和助教授、第 3 講 座, 丸井義仁助教授, 前田式郎講師に深甚の謝意を表します. また本研究にご協力下さいました教室員各位に感謝いたしま ナ.

本論文の要旨の一部は第 70 回日本補緅菌科学会学術大会 (1983 年 10 月 15 日, 千葉), および, 第 40 回岐阜萪科学会例 会（1984年 2 月 18 日，岐阜）において発表した。 


\section{文献}

1）林都志夫，他：義歯と発音，日本歯科医師会雑誌,16(3)： $3 \sim 13,1963$.

2）倉知正和, 他 : 語明度の変化要因と補縟物, 第 1 報, 影欠 損患者について，補緅誌，24（3）：410 417， 1980 。

3）桑原 勉, 他: 語明度の変化要因と補縟物, 第 2 報, スピ 一チェイドについて, 補緅誌, 24 (3)：418 424, 1980.

4）岡原和信, 他: 語明度の変化要因と補縀物, 第 3 報, 唇裂, 口蓋裂患者について, 補緅誌, 24 (3)：425 431， 1980.

5）関根 弘, 他: 義歯の音声学的研究, 第 1 報, 口蓋床によ る調音障害について, 補緅誌, $5: 175 \sim 182,1961$.

6）友松英美：義歯の発音に及ぼす影響について，歯科学報， 31 (3) : 295 329, 1959.

7）松木教夫：全部床義歯患者の発音の研究，(その 2 ), 他党 的障害について, 口病誌, 38 (3):333 362, 1971.

8）山縣健佑, 他：補緅処置の発音に及ぼす影響について, 第 2 報、前歯部の補緅例、補経誌，10:205 213，1966.

9）三浦種敏, 他：新版聴党と音声, 259 275, コロナ社, 東 京, 1980.

10）倉知正和：日本語 5 母音の補緅学的分析, 岐歯学誌,9(2)： 322 348, 1981.

11）丸井義仁：上䪽局部床義歯設計に伴う母音音響相につい て, 補緅誌, 27 (4) : 61 78, 1983.

12) Fant, G. : Acoustic Theory of Speech Production, 93 204, Mouton \& CO. USA, 1961.

13) Flanagan, J.L. : Speech Analysis Synthesis and Perception (Second, Expanded Ed.) Springer-Verlag, New York, 1972.

14) Markel, J.D., Gray, A.H. Jr. : Linear Prediction of Speech, 音声の線形予測，鈴木久喜 (訳)，71 92, コロ 十社, 東京, 1980.

15) Fant, G. : Acoustic Theory of Speech Production, 15 21, Mouton, The University of Chicago Press, 1970.

16）兼子尚道：発音における下面, 唇及び舌運動の研究, 音声 の研究 (母音の部), 日本音声学会創立満 30 年記念論文集: $1 \sim 18,1957$.

17）森田啓一：正常者のパラトグラム，口病誌，3 4(4)：279 309, 1967.

18）伊藤秀美, 他：電気的パトラグラフによる舌の調音と口蓋 形態に関する基礎的研究, 補緅誌, 22 (3)：580 598, 1978.

19）燱田克躬：日本語の構音に関する考察，第一：日本語の口 蓋図ならびに舌図について，口病誌，11：2，136 145, 第二 : 語音の発音に及ぼす人工口蓋および前歯面舌の厚さ
の影阼，口病誌，11：3，195 205, 1937.

20）吉川 弥：全口蓋床が破裂音粠音に及ぼす影整，潾科医学， 28 (3) : 167 207, 1965.

21）藤井輝久, 他：口蓋の形態と語明度との関連性について, 岐歯学誌, 4 (3): 388 391, 1976.

22）桜井和人，他：口蓋床の発音に及ぼす影響について，䖪科 学報, 58 (9) : 417 423, 1958.

23）関根 弘：調音時の下頻運動に関する研究, 第 1 報, 調音 時の下顎の意義について，第 2 報，日本語調音時の下額運 動について, 歯科学報, $59: 1249 \sim 1274,1959$ 。

24）三谷 卓：両唇音と歯音ならびに母音発語の下額切齒点矢 状面運動について，歯科医学，30（5）:1081 1116, 1967.

25）日比野勉：日本語構音に関寸る「レ」線的研究，第 1 篇， 正常人の構音時に於ける発音器官並びに所謂附属管腔の断 面写真, 第 2 篇, 正常人の構音時に於ける発音器官並びに 所謂附属管腔の系統的観察，阪大歯誌， 1:189 215, 1956.

26）和田卓郎：X線映画法による構音運動の解析（特に正常者 ならびに口蓋裂術後患者について)，阪大歯誌，13：105〜 122, 1958.

27）虫本和彦：語音発声時の顔面筋活動に関する研究，第 1 報, 両唇の調音機楎について, 補緅誌, 21 (3) : 495 500, 1977.

28）奥田貫之, 山下 敦, 井上 宏, 藤田孝之, 太田 宏: 日 本語単音のダイナミックパラトグラフィーについて, 補緅 誌, 18 (2) : 143 151, 1974.

29）藤田孝之：実験的局部口蓋床に対する発音の適応につい て, 歯科医学, 40 (2): 219 238, 1977.

30）弘田仁哉：ソナグラフによる発音の研究，第 1 報, 正常音 声の生理学的観察に就て, 歯科学報, 56 (5)：180 189, 1956.

31）関根 弘, 阿部 勤：音声の可視的描写とその補緅学的応 用, 補緅誌, 2 (2)：172 178, 1958.

32）清水健吾：日本語子音の発語明瞭度とソナグラム, 口病誌, 38 (4) : 496 518, 1971

33) Richard, F., Thompson et al Habituation : A Model Phenomenon for the Study of Neuronal Substrates of Behavior Psychological Review, 73 (1) : 16 43, 1966.

34) Philip, M., Groves et al Habituation : A Dual-Process Theory Psychological Review, 77 (5) : 419 450, 1970.

35）林知己夫：比較日本人論，日本と八ワイの調查から，75 122, 中公新書, 東京, 1973.

36）林知已夫：数量化の方法，1 136, 東洋程済新報社, 東 京, 1974.

37）飽戸 弘：数量化理論の適用一現状と問題点一, 特集・数 量化理論, 数理科学, $6: 9 \sim 14$, サイエンス社, 東京, 
1980.

38）柳井晴夫, 岩坪秀一 : 複雑さに挑む科学, 多変量解析入門, 201 252, 娆談社, 東京, 1979.

39) Jakobson, R., Fant, G. and Halle, M. : Preliminaries to Speech Analysis, 音声分析序説, 竹村 滋, 藤村 靖 (訳), 初版, 1 69, 研究社, 東京, 1965.

40）奥田貫之：実験的局部口蓋床の発音に及ぼす影锌，補緅誌， 16 (2) : 362 380, 1972.

41）椎貝敏夫 : 義歯床口蓋板の大小が発音に及ぼす影響に就 て, 歯科学報, $46: 213 \sim 225,1941$.

42) Jespersen, O. : Lehrbuch der Phonetik, Verlag von B.G. Teubner, Leipzig und Berlin, 1913.

43）服部四郎, 他: 日本語の母音, 小林理学研究所報告, 7 (1) : 69 79, 1957.

44）服部四郎：音㹂学, 初版, $147 \sim 167$, 岩波書店, 東京, 1974.

45) Merlean, Maurice Ponty : La structure du Comport- ement, 行動の構造, 渑浦静雄, 木田 元 (訳)， $33 \sim 38$, みすず書房, 東京, 1975.

46) Jones, D. : An Outline of English Phonetics, 9 th ed. 31, Maruzen, Tokyo, 1960.

47) Ladeforged, P. : A Course in Phonetics, 194, Harcourt Brace Joranovich Inc., New York, 1975.

48) Brosnahan, L.F. and Malmberg, B. : Introduction to Phonetics, 85, Cambridge University Press, New York, 1970.

49) Chomsky, N., Halle, M.: The Sound Pattern of English, Harper \& Row, Publishers, New York, 1968.

50) Dell, F. : Generative Phonology, Cambridge University Press, New York, 1980.

51) Schane, S.A. : Generative Phonology, Prentice Hall Inc., New Jersey, 1973.

52）橋本萬太郎, 他：日本語（5), 音韻, $120 \sim 126$, 岩波書 店, 東京, 1978. 